\title{
Increased cellular turnover in response to fluoxetine in neuronal precursors derived from human embryonic stem cells
}

\author{
EUN-AH CHANG ${ }^{1}$, ZEKI BEYHAN ${ }^{1}$, MYUNG-SIK YOO ${ }^{1}$, KANNIKA SIRIPATTARAPRAVAT ${ }^{1}$, TAK KO $^{1}$, \\ KEITH J. LOOKINGLAND ${ }^{2}$, BURRA V. MADHUKAR ${ }^{3}$ and JOSE B. CIBELLI ${ }^{*}, 4,5$
}

\begin{abstract}
${ }^{1}$ Animal Science, ${ }^{2}$ Pharmacology \& Toxicology, ${ }^{3}$ Pediatrics \& Human Development, ${ }^{4}$ Animal Science and Physiology, Michigan State University, East Lansing, MI, USA and ${ }^{5}$ Programa Andaluz de Terapia Celular y Medicina Regenerativa, Andalucía, Spain
\end{abstract}

\begin{abstract}
Previous reports have shown that antidepressants increase neuronal cell proliferation and enhance neuroplasticity both in vivo and in vitro. This study investigated the direct effects of one such antidepressant, fluoxetine, on cell proliferation and on the production of neurotrophic factors in neuronal precursors derived from human embryonic stem cells (hESCs; H9). Fluoxetine induced the differentiation of neuronal precursors, strongly enhancing neuronal characteristics. The rate of proliferation was higher in fluoxetine -treated cells than in control cells, as determined by MTT [3(4,5-dimethylthiazol-2-yl) 2,5-diphenyltetrazolium bromide] assay. The CPDL (cumulative population doubling level) of the fluoxetine-treated cells was significantly increased in comparison to that of control cells $(p<.001)$. Bromodeoxyuridine incorporation and staurosporineinduced apoptosis assays were elevated in fluoxetine-treated cells. Quantitative RT-PCR analysis revealed no significant differences in the expression of neurotrophic factors, brain-derived neurotrophic factor (BDNF); glial-derived neurotrophic factor (GDNF) and cAMP-responsive element-binding protein (CREB) between cells treated with fluoxetine for two weeks and their untreated counterparts. These results may help elucidate the mechanism of action of fluoxetine as a therapeutic drug for the treatment of depression. Data presented herein provide more evidence that, in addition to having a direct chemical effect on serotonin levels, fluoxetine can influence hESC-derived neuronal cells by increasing cell proliferation, while allowing them to maintain their neuronal characteristics.
\end{abstract}

KEY WORDS: human embryonic stem cell, neuronal precursor, fluoxetine, cellular turnover

\section{Introduction}

Human embryonic stem cells (hESCs), initially derived in 1998, show great potential as a source of cells for regenerative medicine and as a model for early human development (Thomson et al., 1998). However, hESCs could have a more immediate use in pharmacotoxicology. To date, such an approach has primarily been used with mouse ESCs (mESCs). For example, Wobus and colleagues (Wobus et al., 1991) generated differentiated cardiomyocytes from mESCs. These cells were then evaluated for chronotropic responses to adrenergic and cholinergic agents and to $\mathrm{Ca}^{2+}$ channel blockers. While the utilization of hESCs for pharmacotoxicology research would be quite valuable, there exist challenges associated with the standardization of culture conditions and methods (Wobus and Boheler, 2005). To this end, Dhara and colleagues (Dhara et al., 2008) have recently shown the advantages of using a neural progenitor cell line grown without a feeder layer, similar to the one we used in this study. The aforementioned techniques can facilitate further study of molecular and biochemical mechanisms in early human neural differentiation and can potentially produce uniform neuronal cells for therapeutic use without concern about contamination from feeder

Abbreviations used in this paper: EB, embryoid body; EST, embryonic stem cell test; FLX, fluoxetine; HESCs, human embryonic stem cells; MEF; mouse embryonic fibroblast; NP, neuronal precursors.

*Address correspondence to: Dr. Jose B. Cibelli. B270 Anthony Hall, Michigan State University, East Lansing, Michigan 48824, USA. Fax: 5174328742. e-mail: cibelli@msu.edu

Supplementary Material (four figures + two tables) for this paper is available at: http://dx.doi.org/10.1387/ijdb.092851ec 
layers.

Depression is the most prevalent and costly mood disorder. It afflicts about $21 \%$ of the world population, and despite the multiple antidepressants available, not all patients respond to pharmacological treatment (Schechter et al., 2005). While the use of postmortem human brain models in pharmacology and developmental toxicology has been developed, overall, human in vitro models to study the effects of drugs in treating mood disorders are scarce (Chen et al., 2001; Ongur et al., 1998; Rajkowska et al., 1999). Current models have inherent limitations, such as limited availability of tissues and anatomical differences that, in turn, can affect the interpretation and repeatability of the results. Most in vivostudies of mood disorders have used laboratory animals, and while useful, they also have shortcomings, i.e., (1) genetic causes of mood disorders are difficult to trace in animals, (2) major primary symptoms of mood disorders are difficult to evaluate, and (3) interspecies differences between animal models (Nestler et al., 2002).

Two mechanisms of depression have been hypothesized: chemical-based and network-based. Over the last few decades, most scientists and clinicians have accepted the premise that depression is caused by a chemical imbalance in the brain that can be corrected with medications. However, in the past decade, an alternative to simplistic chemical-based etiology has arisen; the network hypothesis suggests that depression reflects problems in information processing within neural networks in the brain (Castren, 2005). While intriguing, more research is needed to categorically support the network hypothesis.

Fluoxetine (FLX), a widely used, potent antidepressant commonly known as Prozac, was developed according to the chemical hypothesis. FLX is a selective serotonin reuptake inhibitor (SSRI) with a high selectivity for the 5-hydroxytryptamine transporter (5-HTT). It modulates synaptic serotonin concentrations in the central nervous system (CNS) (Wong et al., 2005). Long-term administration of FLX can induce neural cell proliferation and neurogenesis in the hippocampus and prefrontal cortex of animal models both in vivo and in vitro (Chen et al., 2006; Encinas et al., 2006; Huang and Herbert, 2006; Kodama et al., 2004; Malberg and Duman, 2003; Santarelli et al., 2003). However, the mechanisms by which FLX promotes neural cell proliferation and neuroprotection in vivoare still unknown. Furthermore, the impact
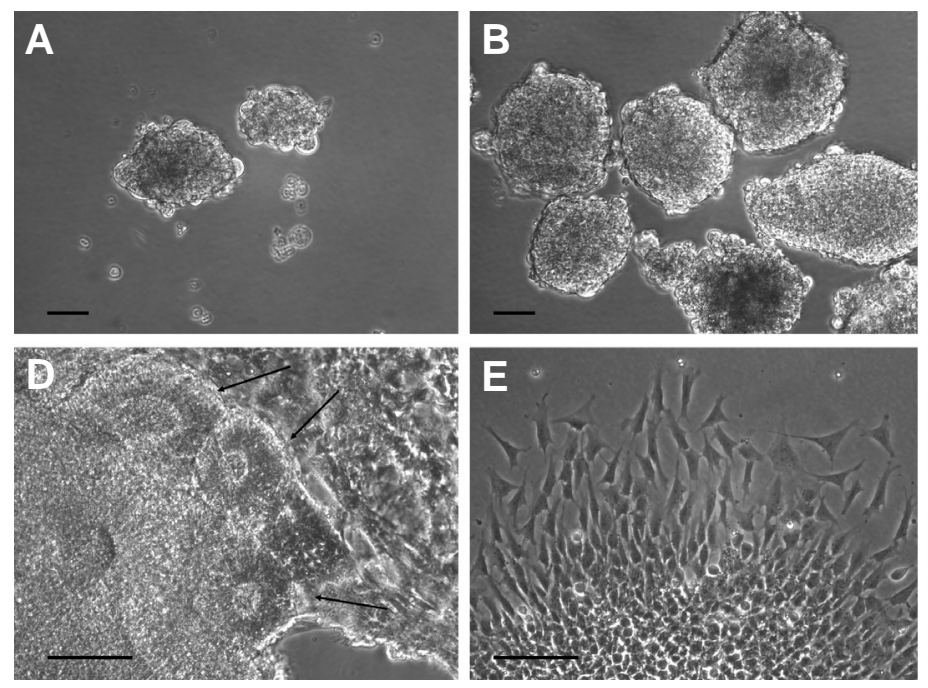

of FLX on the developing/prenatal CNS has not been determined, in part due to the lack of a laboratory model that can recapitulate human fetal development (Morrison et al., 2005).

To examine the effects of FLX and the mechanisms of depression, hESCs with the potential to differentiate into"neuronal precursors can offer a useful alternative to the current in vivo models to study the effect of FLX specifically on early human embryonic development. In the present study, hESC-derived neuronal precursors were treated with FLX at a therapeutically relevant concentration and for the period required for clinical efficacy. During the treatment period, we evaluated the effects of FLX on cell proliferation, cell differentiation patterns, and expression of neurotrophic factors. The results presented here provide new evidence that FLX can indeed influence neuronal cells in vitro, supporting to the notion that an SSRI not only can correct chemical imbalances in the CNS but can modify its cellular architecture as well.

\section{Results}

\section{Characteristics and differentiation of hESC-derived NPs af- ter fluoxetine treatment}

To avoid further potential contamination from feeder cells, which could alter accurate quantification of phenotypic markers during analysis, the differentiation of hESCs into neuronal precursors (NPs) was performed in the absence of any stromal cell line (Fig. 1). Generated hESC-derived NP cells showed a stable, normal karyotype (46, XX) (Suppl. Fig. 2).

Immunofluorescence and RT-PCR analyses demonstrated that the hESC-derived NPs were strongly positive for nestin, PSANCAM, and $\beta$-tubulin. Neuronal differentiation was assessed by determining the number of cells expressing neuronal markers as a percentage of total cells counted in a selected area. The percentage of nestin-positive $\left(^{+}\right.$) cells was $88.2 \pm 3.35 \%$, while percentages for PSA-NCAM ${ }^{+}, \beta / l l-t u b u l i{ }^{+}, \mathrm{MAP}^{+}$, and seroto$\mathrm{nin}^{+}$were $67.9 \% \pm 3.04 \%, 78.5 \% \pm 6.45 \%, 50.6 \% \pm 11.5 \%$, and $29.3 \% \pm 4.95 \%$, respectively. A lower percentage of cells expressed GFAP, CK-8, RIP, and TH, with percentages of $5.5 \% \pm$ $3.2 \%, 3.1 \% \pm 2.7 \%, 2.7 \% \pm 1.5 \%$, and $1.3 \% \pm 0.8 \%$, respectively (Fig. 3A). None of the cells expressed Oct4 (data not shown). Therefore, the hESC-derived NP cells expressed the character-

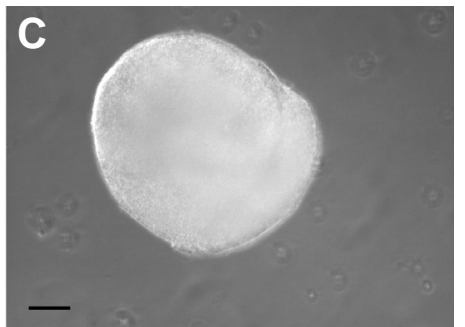

Fig. 1. Differentiation and isolation of hESC-derived neuronal precursors (NPs). (A) hESC clumps floating on day 9. (B) Embryoid bodies (EBS) grown in DMEM/F12 with N2 supplementation for 8 days. (C) By day 18, EBs were clearly demarcated with a smooth surface. (D) After attachment, EB formed neuronal rosettes (arrow). (E) NPs migrating from the periphery of neuronal rosettes. (F) Dissociated single NPs were propagated as attached monolayer cultures. Scale bars $A, B, C, 50 \mu \mathrm{m} ; D, E, F, 1 \mathrm{~mm}$. 


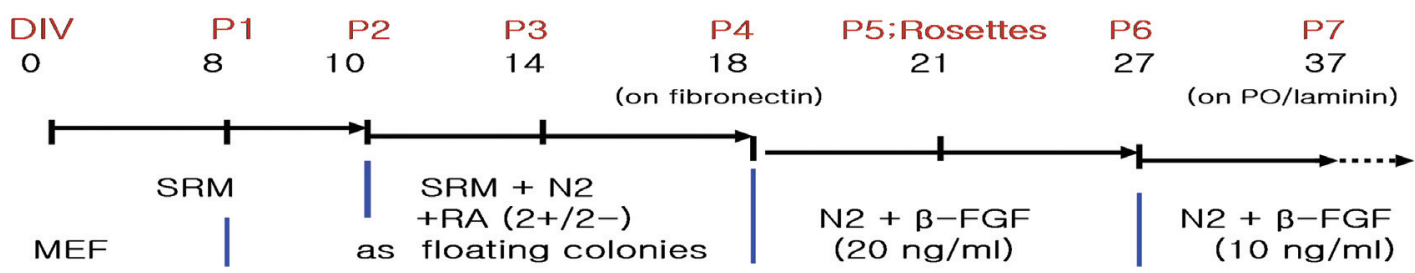

Fig. 2. Schematic representation shows culture conditions and protocol of neuronal differentiation. $h E S C s$ were plated on MEF feeders for eight days. hESC colonies were mechanically isolated and replated in feeder-free dishes as floating colonies (embryoid bodies; EBs) until day ten. EBs were attached on fibronectin-coated plates. Neural rosettes formed on days 21-27, were mechanically isolated and replated on poly-ornithine/laminin-coated plates. Neuronal precursors derived from neural rosettes were propagated in the presence of FGF-2 as attached monolayer cultures and passaged weekly.

istic markers of early neuronal cells. The fact that only a small percentage of cells were immunoreactive to RIP and CK-8 antibodies suggests that glial and epithelial cells were the least abundant types of cell in the cultures. The cells used in this study are fully capable of giving rise to astroglia, oligodendrocytes and neurons (data not shown) however, our goal in this differentiation protocol was to induce the NPs specifically into neuronal lineage. Semiquantitative RT-PCR analysis also showed results similar to the immunofluorescence data (Fig. 3B).

Following two weeks of culture with FLX, RT-PCR and immunofluorescence analyses showed that NPs expressed significantly more neuronal markers than control cells and continued to be negative for glial markers (Fig. 4A, 4B). No differences in the expression of MAP2 and serotonin were observed between control cells and those treated with FLX (Fig. 4A). However, the expressions of nestin detected by RT-PCR in control and FLXtreated cells are lower than Immunofluorescence analyses, This might be due to different transcriptional regulation and protein turn-over rates (Di Lieto et al., 2007).

\section{Cell growth pattern of fluoxetine -treated NPs, with or without FGF-2}

This study initially evaluated the influence of FGF-2 on FLXtreated cells.

NPs were cultured under four factorial combination of $4 \mathrm{ng} / \mathrm{ml}$ FGF-2 and $0.5 \mu \mathrm{g} / \mathrm{ml} \mathrm{FLX(FLX-}$ /FGF-2+; Suppl Fig. 3-A1, FLX+/FGF-2+; Suppl Fig. 3-A2, FLX-/FGF-2-; Suppl Fig. 3B-, and FLX+/FGF-2-; Suppl Fig.3B-2). In the absence of FGF-2, NPs treated with FLX showed a clear difference in their morphology and growth pattern compared to those of non-FLX treated cells in two weeks. Numerous cell aggregates, similar to neurospheres were formed in FLX treated cells as opposed to scattered individual cells of control NPs (Suppl Fig. 3-B1,B2). When FGF-2 was present in the media, FLX treated and non-FLX

B treated cells were similar in their morphological characteristics with the appearance of large cell clumps, regardless of FLX treatment (Suppl Fig. 3-A1,A2). Due to the masking effect of FGF2 on FLX treatment we observed, subsequent experiments were conducted without FGF-2 treatment.

\section{Effects of fluoxetine on cell proliferation and death in neu- ronal precursors}

The effects of FLX concentration on cell proliferation rates were determined using an MTT assay. When $10 \mu \mathrm{g} / \mathrm{ml}$ of FLX was used, $50 \%$ of NPs died within $24 \mathrm{hrs}$ of exposure to the compound. When the dosage was reduced to $1 \mu \mathrm{g} / \mathrm{ml}$ of $\mathrm{FLX}$, proliferation rates were similar to those of the control and of cells treated with $0.5 \mu \mathrm{g} / \mathrm{ml}$. However, $50 \%$ of cells died after fourteen days of treatment with $1 \mu \mathrm{g} / \mathrm{ml}$. On the other hand, NPs survived for up to fourteen days in less than $0.5 \mu \mathrm{g} / \mathrm{ml}$ of FLX, as did the control cells. An FLX concentration of less than $0.5 \mu \mathrm{g} / \mathrm{ml}$ is within the therapeutic range for FLX in adult human plasma, indicating that $F L X$ has no cytotoxic effects as clinically used (Suppl Fig. 4). Briefly, the MTT assay showed that the proliferation rate of FLX-treated cells
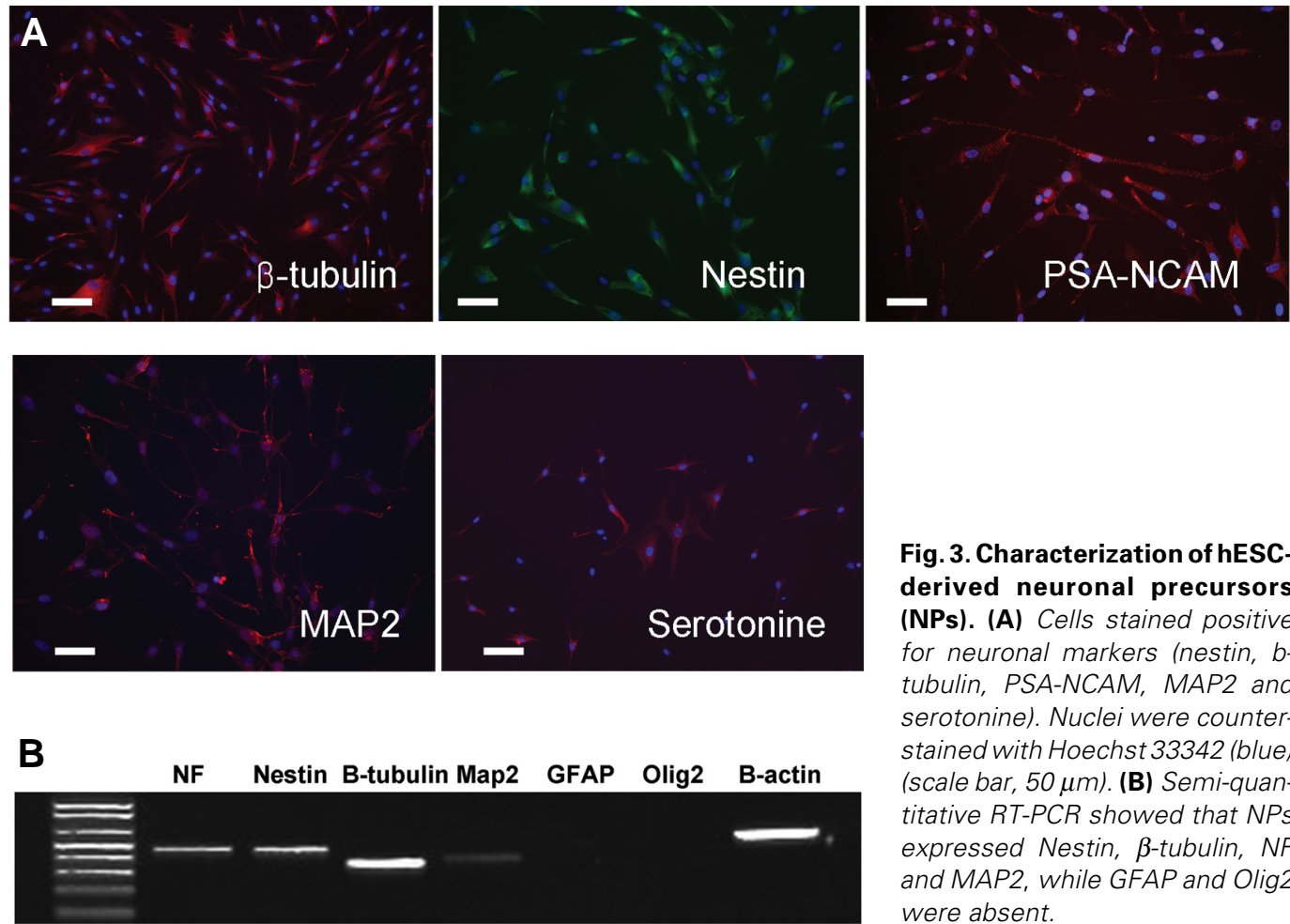

Fig. 3. Characterization of hESCderived neuronal precursors (NPs). (A) Cells stained positive for neuronal markers (nestin, btubulin, PSA-NCAM, MAP2 and serotonine). Nuclei were counterstained with Hoechst 33342 (b/ue) (scale bar, $50 \mu \mathrm{m}$ ). (B) Semi-quantitative RT-PCR showed that NPS expressed Nestin, $\beta$-tubulin, NF and MAP2, while GFAP and Olig2 were absent. 

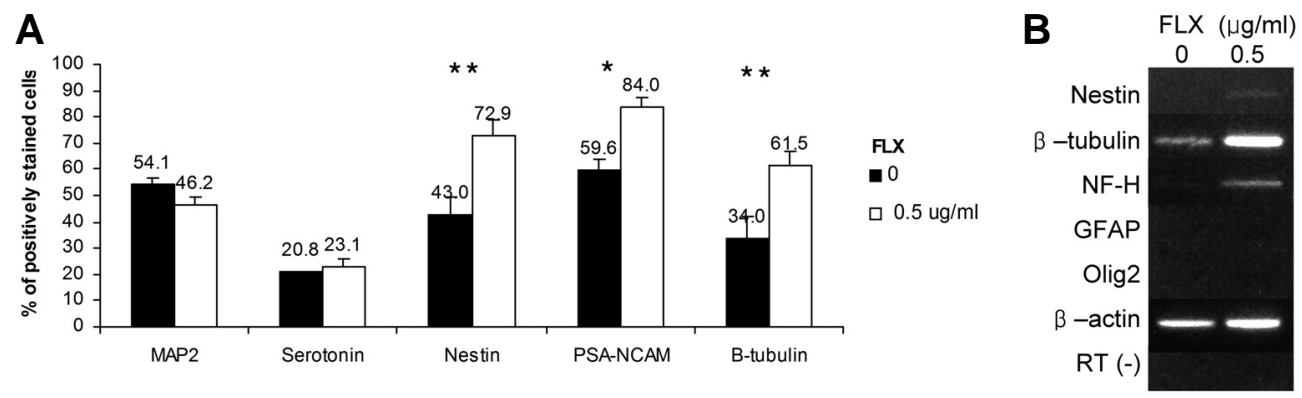

Fig. 4. Characteristics of hESC-derived neuronal precursors (NPs) changed after 2 weeks of fluoxetine treatment. (A) Immunostaining showed that rates of Nestin, PSA-NCAM and $\beta$-tubulin positive staining significantly increased compared to that in control NPS $\left(^{* *}=p<.01,{ }^{*}=p<.05\right)$. Rates of MAP2 and Serotonin positive NPs did not change. (B) RT-PCR showed that expression of Nestin, NF and $\beta$-tubulin were more increased in fluoxetine(FLX)-treated than in control cells. Fluoxetine-treated cells continued to be negative for glial markers (GFAP and Olig2). No difference in expression of MAP2 or serotonin was observed between control cells and those treated with fluoxetine.

increased more than those of control cells at less than $0.5 \mu \mathrm{g} / \mathrm{ml}$ of FLX during the first week, despite showing no statistically significant difference between different concentrations of FLXtreated NPs in overall proliferation rates.

CPDL was measured with and without FLX to determine the long-term proliferative potential of FLX-treated NPs. After 45 days of continuous passaging, totals of 6.81 and 5.03 CPDLs were found in FLX-treated and control cells, respectively. When the cells were passaged at regular intervals (every five to seven days), the CPDL of FLX-treated NPs was significantly increased at day 15 (p<.001; Fig. 5).

To examine the influence of FLX on DNA synthesis, the number of BrdU-positive NPs was counted by immunostaining at days 0,3 , and 7 after FLX treatment $(0.5 \mu \mathrm{g} / \mathrm{ml})$. The percentage of BrdU-positive cells at days three $(54.9 \% \pm 0.3 \%$,) and seven $(55.4 \% \pm 0.4 \%)$ was significantly increased in FLX-treated cells compared to controls (Fig. 6, Table 1).

The rate of apoptosis induced by staurosporine (STS) in FLXtreated NPs was measured using DNA fluorochrome Hoechst staining. Upon exposure of the control cells to STS $(200 \mathrm{nM})$ for $20 \mathrm{hrs}$, about $7.35 \%$ of the cells died at day 0 . When NPs were treated with $0.5 \mu \mathrm{g} / \mathrm{ml} \mathrm{FLX}$, the percentage of apoptotic cells was

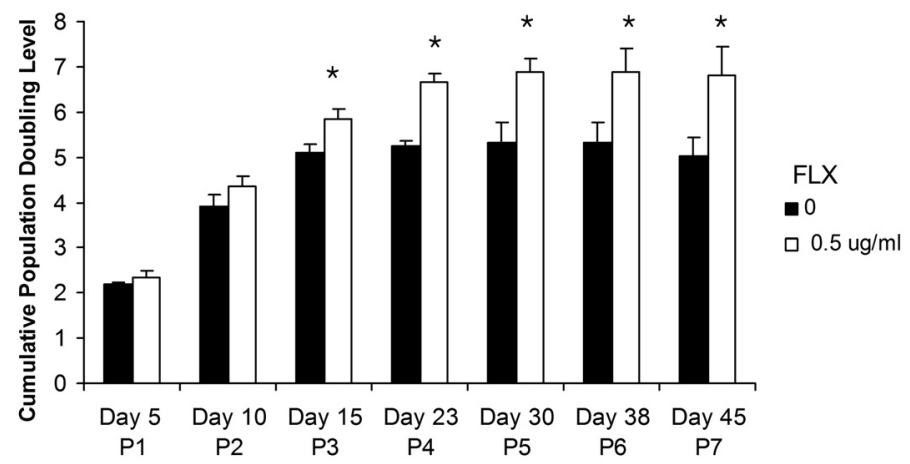
expression of these genes showed no statistically significant differences between FLX-treated and control cells (data not shown).

\section{Effects of fluoxetine on production of neurotrophic factors}

Considering that changes in the levels of neurotrophic factors can indicate neuronal plasticity in the brain (Benninghoff et al., 2002; Castren et al., 2007; Nibuya et al., 1996), we evaluated changes in the production of brain-derived neurotrophic factor (BDNF), glial-derived neurotrophic factor (GDNF), cAMP-responsive element-binding protein (CREB), 5-hydroxytryptamine receptor 1A (5HTR1A), 5-hydroxytryptamine receptor 2A (5HTR2A) and 5-hydroxytryptamine transporter (5HTT), as measured by real-time RT-PCR analysis after two weeks of FLX treatment. We also measured protein expression of BDNF, CREB, p-CREB (phosphorylated CREB) and 5HTT by western blotting after two

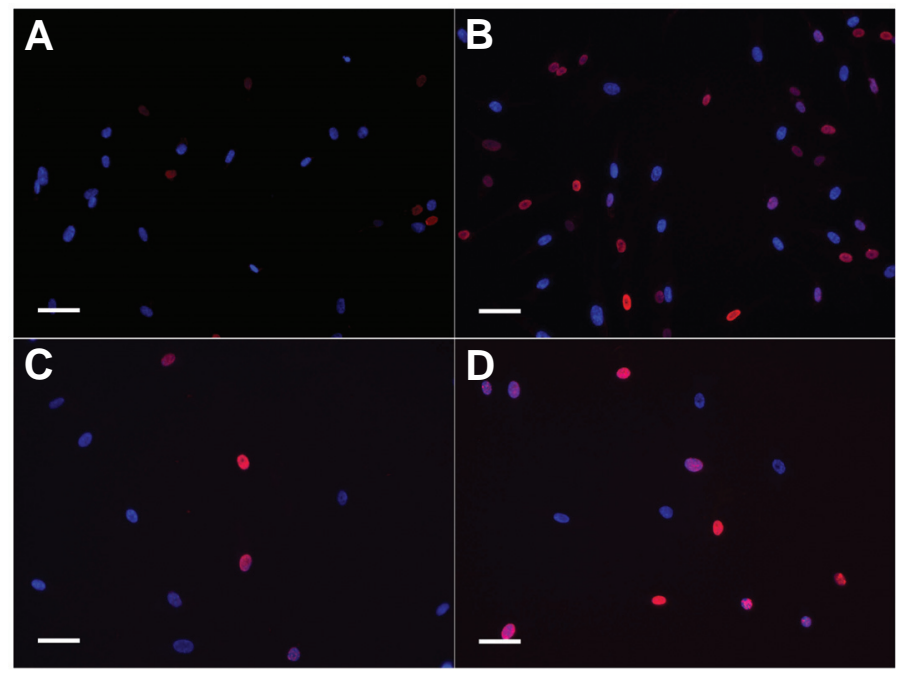

Fig. 5 (Left). Cell proliferation assays for hESC-derived neuronal precursors (NPs) with and without fluoxetine. Cumulative population doubling level (CPDL) of NPS cultured with and without fluoxetine ( $F L X) . C P D L$ of FLX-treated cells were significantly increased from day 15 until day $45\left({ }^{*}=p<.001\right)$.

Fig. 6 (Right). Immunofluorescent BrdU-incorporation of neuronal precursors (NPs). Percentage of BrdU-positive cells (red) was significantly increased in hESC-derived NPs cultured with fluoxetine $(0.5 \mu \mathrm{g} / \mathrm{ml})$ for 3 days (B) and 7 days (D) $(p<.05$ and $p<.01$, respectively), compared with control NPs cultured without fluoxetine for 3 and 7 days $(\mathbf{A}, \mathbf{C})$. Scale bar, $50 \mu \mathrm{m}$. 
TABLE 1

PERCENTAGE OF BrdU-IMMUNOPOSITIVE NEURONAL PRECURSORS, WITH AND WITHOUT FLUOXETINE, OVER TIME

\begin{tabular}{cccc} 
& \multicolumn{3}{c}{ Time of drug treatment (\% of BrdU-labeled cells) } \\
\cline { 2 - 4 } Drug conc. $(\mu \mathrm{g} / \mathrm{ml})$ & Day 0 & Day 3 & Day 7 \\
\hline 0 & $41.4 \pm 0.2$ & $40.1 \pm 0.1$ & $33.0 \pm 0.2$ \\
0.5 & $42.1 \pm 0.4$ & $54.9 \pm 0.3$ & $55.4 \pm 0.4$ \\
\hline
\end{tabular}

$\left({ }^{*} ; p<.05,{ }^{* *} ; p<.01\right)$

weeks of FLX treatment. We found no statistically significant differences in gene and protein expression between the FLXtreated cells and controls (data not shown).

\section{Discussion}

Drug development presents numerous challenges beyond the demonstration of efficacy. Of great concern is the inability to anticipate toxicity in specific tissues, as well as potential teratogenicity. While numerous animal models can help predict the risks of drugs before the initiation of clinical trials, there is a tremendous need for human in vitro models that can be used to evaluate toxicity early in development.

Over the past ten years, ECVAM (the European Center for the Validation of Alternative Methods) has conducted several in vitro embryotoxicity tests - such as the whole-embryo culture (WEC) test, the rat limb bud micromass (MM) test, and the embryonic stem cell test (EST) - to evaluate chemicals known to have embryotoxic potential in vivo. These tests also very effectively reduce the number of in vivo animal experiments conducted (Genschow et al., 2002; Scholz et al., 1999). The most useful embryotoxicity test is the EST, which uses two well-established cell lines: a pluripotent mouse embryonic stem cell (mESC) line (D3) and differentiated 3T3 fibroblasts (Scholz et al., 1999). EST studies take advantage of the potential of mESCs to detect embryotoxicity in vitro. However, in vitrotests using mESCs have limitations due to species-specific developmental differences (Pouton and Haynes, 2007). Accordingly, hESCs can provide a more useful model to test new therapeutic compounds and also can be used as an in vitro model to test whether a specific drug promotes or interferes with lineage specific differentiation pro-

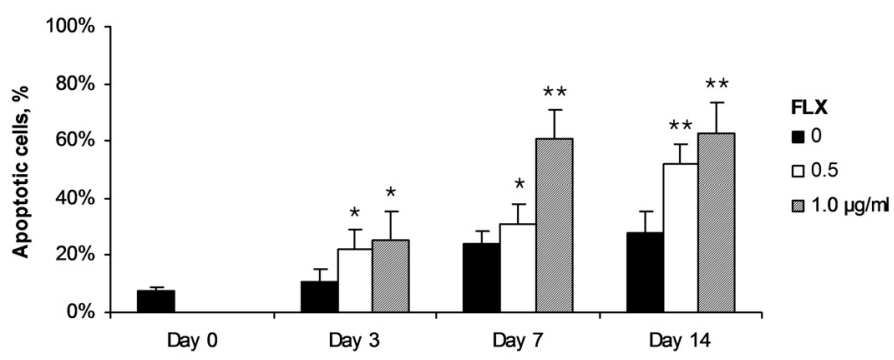

Fig. 7. Staurosporine-induced apoptosis in neuronal precursors (NPs). Fluoxetine (FLX)-treated cells were exposed to $200 \mathrm{nM}$ staurosporine (STS) for $20 \mathrm{~h}$. Apoptosis was evaluated by Hoechst 33342 staining. Fragmented nuclei with condensed chromatin, which reliably indicate apoptosis were counted. Since FLX and STS treatment were started simultaneously, only one apoptotic index is plotted at DO. Data are presented as mean \pm SE (\%). (*; $\left.p<.05,{ }^{*} ; p<.001\right)$. gram.

FLX, currently one of the most widely prescribed antidepressant medications. While it is known that FLX targets early progenitor cells in the adult brain (Encinas et al., 2006), its effect upon the developing brain has not been completely determined, in part due to the lack of a proper human model. In an effort to identify the therapeutic and toxic impacts of FLX in vivo, we describe an experimentally novel approach to examining various aspects of FLX's effects on NPs derived from hESCs.

The results showed that FLX-treated NPs proliferated within one week after the addition of the drug and to a greater degree than untreated cells. This indicates that the mitogenic activity induced by FLX occurred during the early phases of these cultures. Our findings differ from previous studies, which argued that cell proliferation occurred after two or three weeks of FLX treatment in vivo or in vitro (Kodama et al., 2004; Malberg and Duman, 2003; Manev et al., 2001; Santarelli et al., 2003). The current study, however, produced results similar to those of Chen et al.,2007), who observed cell proliferation under in vitro conditions after seven days, though they used different cell type and culture conditions. It is highly likely that the discrepancies observed are due to differences in the experimental design - i.e., in vivo or in vitro tests.

The MTT assay and CPDL data demonstrated that there was a different proliferative effect between the two tests observed in the cells, depending primarily on the different cell culture methods in vitro. For the MTT assay, cells were not passaged. However, for the CPDL analysis, NPs were passaged at regular intervals, and they survived for up to 45 days. Control cells plateau their proliferation rate from Day 15 onward, while FLX-treated cells plateau on their proliferation on Day 23. We conclude that the effect on proliferation rate was higher in FLX-treated cell, as measured by CPDL. The results of the MTT assay showed that FLX has no cytotoxic effects at less than therapeutic concentrations $(<0.5 \mu \mathrm{g} / \mathrm{ml})$; however, this does not rule out the possibility of any teratogenic effect.

In the present study, the results of the STS-induced apoptosis assay were affected by the concentrations and time courses of the administration of FLX. Apoptosis increased as the concentrations and/or time increased, but no changes in apoptotic gene expression (Bcl-2, Bcl-xl, and Bax). This indicates that although induced apoptosis is usually associated with changes in the amount of apoptotic gene transcripts, induced without changes in the transcript level of these genes probably due to posttranscriptional induction/regulation of the pathway. Previous studies examined the effects of FLX on apoptosis with different types of cell, such as adult neurons, hepatocytes, lymphoma cells, and neuroblastoma cells (Chen et al., 2007; Chiou et al., 2006; Koch et al., 2003; Lee et al., 2001; Levkovitz et al., 2005; Nahon et al., 2005; Serafeim et al., 2003). However, these studies used nonhuman CNS cells and animal models. Previous reports have shown conflicting evidence regarding the effect of FLX on apoptosis. Some studies showed an increase in apoptotic activity due to FLX in different cell lines using various methods (Koch et al., 2003; Levkovitz et al., 2005; Serafeim et al., 2003), while others found an increase in antiapoptotic activity (Chen et al., 2007; Chiou et al., 2006; Lee et al., 2001; Nahon et al., 2005). These conflicting findings may have resulted from differences in cell lines, FLX concentrations, or the duration of treatment. Our results, similar to those reported 
by others (Koch et al., 2003; Levkovitz etal., 2005; Serafeim etal., 2003), detected an increase in apoptotic activity within one week of FLX treatment.

Interestingly,"FLX treatment increased in both cell proliferation and induced apoptotic activity in our experiments, consistent with the findings in the study by Sairanen et al. (2005) (Sairanen et al., 2005), which was conducted using an in vivo animal model after ten and 20 days of FLX treatment. We provide further evidence that FLX may activate cell proliferation and augment the effect of apoptotic agents in hESC-derived NPs.

The observed cellular characteristics and differentiation patterns demonstrate that FLX enhanced the neuronal rather than the glial properties. Markers increased by FLX were early neuronal markers, such as nestin, PSA-NCAM and $\beta$-tubulin. PSANCAM-induced expression by FLX is of interest since it has been described as a gene involved in neurogenesis (Kiss and Rougon, 1997; Varea et al., 2006). In addition, PSA-NCAM is closely associated with $\mathrm{p}$-CREB involved in neuroplasticity and cell survival (Nakagawa et al., 2002). Therefore, the pattern of PSANCAM expression and cell proliferation observed in this study supports the hypothesis that one mechanism of action of FLX is via neurogenesis, providing further evidence that the mechanism of depression is associated with abnormal processing of the neural network.

Until recently, studies of depression and antidepressants have focused on intracellular pathways, which are known to be activated by a number of extracellular signals, such as growth factors, stress, and neurotransmitters (Malberg, 2004; Malberg and Blendy, 2005). These signal pathways regulate various cellular processes associated with neuroplasticity and neurogenesis. The transcription factors CREB and BDNF are the targets of diverse types of antidepressants (Blendy, 2006; De Foubert et al., 2004; Josselyn and Nguyen, 2005). Chronic FLX administration promotes neurogenesis and synaptogenesis in the adult hippocampus (Grote et al., 2005; Malberg et al., 2000), as well as increased expression of the neurotrophins BDNF and GDNF (Hisaoka et al., 2007; Nibuya et al., 1995). These molecular and cellular events seem necessary to mediate the therapeutic effects of FLX. However, there are conflicting reports on the effect of FLX on CREB and BDNF. Some studies have observed increases in CREB and BDNF following in vivo FLX administration, and the authors attributed this increase to the type of anatomical brain lesions and to their experimental designs (Chen et al., 2001; Malberg and Blendy, 2005; Nibuya et al., 1995). Other studies were unable to detect increases in CREB or BDNF in response to FLX (Dias et al., 2003). The present study found no difference in the expression of neurotrophins in response to $F L X$ in vitro. All of the studies conducted to assess the effect of FLX employed either brain-derived primary cultures or animal models, with generally using much higher concentrations of the drug. These differences may account for the discrepancy between the published data and ours. This may also suggest intrinsic differences between hESderived NPs and primary cultures of the same type of cells directly isolated from animals or human. Considering the fact that the studies of FLX and tumor cell lines from lymphoma, neuroblastoma, pheochromocytoma and glioblastoma can also increase neurotrophic factors and apoptotic activities (Bartholoma et al., 2002; Hisaoka et al., 2005; Koch et al., 2003; Levkovitz et al., 2005).
Although pharmacotoxicology uses many cell culture systems, current in vitro models, such as primary cultures or established cell lines, are quite different from in vivo analogs (Gottlieb, 2002; Wobus et al., 1994).

Primary culture of human neural tissue is generally impractical, and while some neuronal cell lines can be induced to express markers of mature neurons under special culture conditions, they often fail to represent the properties of specialized neurons. This is often due, in part, to the origin of these cells in CNS-derived tumors, to a loss of viability, and to changes in phenotypic properties as a result of long-term culture.

Our study can help to elucidate the mechanism of action of FLX as a therapeutic drug for the treatment of depression by providing a valid alternative to current in vitro models. Their most attractive characteristic is their capacity to renew indefinitely while maintaining their differentiation potential. It is worth mentioning that standardization may be a challenge when working with hESCs. It has been shown that culture conditions will alter the gene and protein expression in these cells and, as a consequence, variations may occur between replicates of the same study and among studies, even though the cell line might be the same. In addition, the process for generating large numbers of hESCs is labor intensive, and the possibility of irreversible genetic or epigenetic changes during experiments is always present (Pouton and Haynes, 2007). Regardless, hESCs can provide insights into a drug's mechanisms of action and can reveal new targets for currently prescribed pharmaceuticals. Human ESCs may also help predict and avoid potential drug toxicity in humans. It is therefore essential that research and optimization of their use for these purposes continue.

\section{Materials and Methods}

All reagents were purchased from Sigma unless otherwise indicated.

\section{Cell culture and differentiation}

\section{Human embryonic stem cell culture}

Human H9 ESCs (passages 29 to 31) with a stable, normal (46, XX) karyotype were cultured as described previously (Zhang et al., 2001). Briefly, cells were cultured on a mitotically inactive feeder layer of mouse embryonic fibroblasts. The culture medium consisted of Dulbecco's Modified Eagle's Medium (DMEM/F12; Invitrogen, Rockville, MD), 20\% knockout serum replacement (Invitrogen), $0.1 \mathrm{mM} \beta$-mercaptoethanol, 4 $\mathrm{ng} / \mathrm{ml} \mathrm{FGF-2} \mathrm{(Invitrogen),} \mathrm{1 \%} \mathrm{nonessential} \mathrm{amino} \mathrm{acids} \mathrm{(Invitrogen),} \mathrm{and}$ $2 \mathrm{mM}$ L-glutamine (Invitrogen). The undifferentiated state of the hESCs was confirmed by characteristic morphology monitoring and immunostaining with anti-Oct4 antibody (Suppl. Fig. 1). All cultures were maintained in a humidified incubator with $5 \% \mathrm{CO}_{2}$ at $37^{\circ} \mathrm{C}$.

\section{Generation of hESC-derived neuronal precursors}

A modification of the procedure described by Zhang was used to isolate hESC-derived neuronal precursors (Zhang et al., 2001). Human ESCs colonies were mechanically isolated when they reached a diameter of 1 to $1.5 \mathrm{~mm}$. Intermediate-sized clumps of cells were transferred to 35 $\mathrm{mm}$ dishes (BD Biosciences, Bedford, MA), and cultured in ESC medium at $37^{\circ} \mathrm{C}$ for two days (Fig. $\left.1 \mathrm{~A}\right)$. Cell colonies that grew into nonattached embryoid bodies (EBs) were removed and transferred to new $35 \mathrm{~mm}$ dishes.

Floating EBs were cultured in DMEM/F12 with $1 \% \mathrm{~N} 2$ supplement (Invitrogen), medium (basal neural medium) and hESC medium (1:1) for four days. Subsequently, the EBs were transferred into a new dish and 
were cultured with $100 \%$ basal neural medium plus $3 \mu \mathrm{M}$ retinoic acid $(2+/$ 2-; Fig. 1B and 1C). After ten days, well-demarcated EBs were attached to fibronectin-coated (Invitrogen) plates and cultured for nine days with basal neural medium plus $20 \mathrm{ng} / \mathrm{ml}$ FGF-2. A significant number of rosettes developed in the center of the differentiating EBs (Fig. 1D).

Rosette colonies were isolated, using a Pasteur pipette, and dissociated with a micropipette (Fig. 1E). Cells were replated on poly-Lornithine/laminin-coated plates $(50 \mu \mathrm{g} / \mathrm{ml}$ of poly-L-ornithine, $20 \mu \mathrm{g} / \mathrm{ml}$ of laminin) and cultured in basal neural medium containing $10 \mathrm{ng} / \mathrm{ml}$ FGF-2 for ten days (Fig. 1F). Subsequently, the cells, now called neuronal precursors (NPs), were cultured as a monolayer in basal neural medium containing $4 \mathrm{ng} / \mathrm{ml}$ FGF-2 (Fig. 2). NPs reached proliferative senescence at the tenth passage.

\section{Treatment of hESC-derived neuronal precursors with fluoxetine}

Stock solutions of FLX were prepared using DMSO and were diluted directly into the culture media at final FLX concentrations of 0.5 $\mu \mathrm{g} / \mathrm{ml}$. NPs were cultured in DMEM/F12-supplemented N2 culture medium in the presence of FLX. FGF-2 was excluded from the cell culture medium when the cells were treated with FLX. Culture medium was changed every two days and only DMSO was added to controls. NPs were cultured for two weeks in $0.5 \mu \mathrm{g} / \mathrm{ml}$ of $F L X$, at which point they were evaluated using immunostaining, RT-PCR, western blotting and real-time RT-PCR. For the MTT (3(4,5-dimethylthiazol-2-yl) 2,5diphenyltetrazolium bromide) assay, NPs were cultured for various times (for 24, 48, and $72 \mathrm{hrs}$ and for one and two weeks) in different concentrations of FLX (from 0 to $10 \mu \mathrm{g} / \mathrm{ml}$ ). Cumulative population doubling level (CPDL) in continual subculture was calculated taking into account the total seeded and the total harvested cells from each culture dish. To determine the CPDL, NPs were cultured for 45 days in $0.5 \mu \mathrm{g} / \mathrm{ml}$ of FLX and passaged at five- to seven-day intervals. For the bromodeoxyuridine (BrdU) incorporation assay, NP cells were cultured for $72 \mathrm{hrs}$ and one week in $0.5 \mu \mathrm{g} / \mathrm{ml} \mathrm{FLX.} \mathrm{For} \mathrm{the} \mathrm{staurosporine-}$ (STS-)induced apoptosis assay, NP cells were cultured for $72 \mathrm{hrs,} \mathrm{one}$ week, and two weeks in $0.5 \mu \mathrm{g} / \mathrm{ml}$ and $1.0 \mu \mathrm{g} / \mathrm{ml}$ of FLX.

\section{Karyotype analysis}

Karyotyping was performed on the NPs using standard methods (G-banding) by Cell Line Genetics (Madison, WI). At least 20 cells from each sample were examined.

\section{Characterization of hESC-derived neuronal precursors}

\section{Immunofluorescence and quantification of immunopositive NPS}

Protein expression in hESCs and NPs was analyzed by immunofluorescence. Cells were fixed with $4 \%$ paraformaldehyde and permeabilized with $0.05 \%$ Triton X-100. After blocking with $3 \%$ bovine serum albumin, cells were incubated with primary antibodies. The following primary antibodies and dilutions were used: mouse anticlass III $\beta$-tubulin-Tuj1, 1:500; rabbit anti-glial fibrillary acidic protein (GFAP), 1:5000; rabbit anti-nestin, 1:1000 (Abcam); mouse anticytokeratin-8 (CK-8), 1:200; mouse anti-microtubule-associated protein 2 (MAP2), 1:500; goat anti-Oct4, 1:100 (Santa Cruz Biotechnology, Santa Cruz, CA); mouse anti-receptor interacting protein (RIP), 1:1000; mouse anti-polysialylated neuronal cell adhesion molecule (PSA-NCAM), 1:250 (Chemicon, Temecula, CA); and rabbit antityrosine hydroxylase (TH), 1:1000 (Pel-freez, Arkansas). The antigens were visualized under UV light using one of the following secondary antibodies: Alexa Fluor 594 or 488 (Molecular Probes, Eugene, OR). Cells were counterstained with $1 \mu \mathrm{g} / \mathrm{ml}$ of Hoechst 33342 for $10 \mathrm{~min}$ at room temperature. Semiquantitative measurement of immunopositive cells was determined using a 20X Zeiss LSC System objective lens mounted on a Nikon TE 2000-U microscope. More than 1,000 immunopositive cells for each primary antibody were photographed and counted. The number and the percentage of immunopositive cells were calculated in relation to the total number of Hoechst-positive cells (>1,000 cells).

\section{$R T-P C R$}

Total RNA was extracted from $\mathrm{hESC}$-derived NPs before and after two weeks with and without FLX, using the Picopure RNA Isolation Kit and following the manufacturer's instructions (Arcturus, Sunnyvale, CA). After DNAse I digestion, cDNA was prepared from $1 \mu \mathrm{g}$ total RNA, using the SuperScript III RT-PCR Kit (Invitrogen) as instructed by the manufacturer. Primer pair sequences are shown in Suppl. Table 1. The amplification procedure consisted of 30 cycles (denaturation at $94^{\circ} \mathrm{C}$ for $30 \mathrm{sec}$, annealing at $58^{\circ} \mathrm{C}$ for $40 \mathrm{sec}$, and extension at $72^{\circ} \mathrm{C}$ for $45 \mathrm{sec}$ ). Amplification reactions were conducted in a final volume of $25 \mu \mathrm{l}$ containing $1.0 \mu \mathrm{lcDNA}, 100 \mathrm{pmol}$ each of forward and reverse primer and of PCR Master Mix (Promega, Madison, WI). RT-PCR products were separated by electrophoresis on $1 \%$ agarose gels and stained with ethidium bromide.

\section{Assessment of proliferation, apoptosis, and production of neu- rotrophic factors in fluoxetine -treated neuronal precursors}

\section{MTT assay}

MTT assays were performed at $0,24,48$, and $96 \mathrm{hrs}$ and at one and two weeks after FLX treatment. NPs growing without FLX were used as negative controls. The MTT assays were performed as previously described (Scholz et al., 1999). Briefly, 2 B $10^{4}$ NPs were seeded on 24-well plates and grown in the presence of FLX at $0,0.1,0.5,1,10$, and $100 \mu \mathrm{g} /$ $\mathrm{ml}$. MTT $(400 \mu \mathrm{g} / \mathrm{ml})$ was added to each well for a $3 \mathrm{hr}$ incubation period. $\mathrm{HCl}$-isopropanol $(0.04 \mathrm{M})$ was added to the cultures, and cells were incubated again for $15 \mathrm{~min}$ at $37^{\circ} \mathrm{C}$. The absorbance at $570 \mathrm{~nm}$ was measured using a spectrophotometer (Beckman Coulter, Inc., Fullerton, $\mathrm{CA})$. Results were expressed as the percentage of blue formazan absorbance in treated cells relative to that in cells without FLX. Experiments were run in triplicate.

\section{Cumulative population doubling level (CPDL)}

FLX-treated $(0.5 \mu \mathrm{g} / \mathrm{ml}) \mathrm{NPs}$ were continuously passaged in neural media without FGF2 for 45 days, and each passage was five to seven day interval. The CPDL was calculated to determine their proliferation potential. Nontreated NPs, cultured in same condition but without FLX, were used as controls. The CPDL at each passage was calculated from the cell count using the equation $\ln (N f / N) / \ln 2$, where $N i$ and $N f$ are the initial and final cell numbers, respectively, and In is the natural log(Lin et al., 2005).

\section{5-Bromo-2-deoxyuridine (BrdU) incorporation assay}

FLX-treated NP and control cells were cultured overnight with $30 \mu \mathrm{g} /$ $\mathrm{ml}$ of BrdU prior to immunostaining. Cells were fixed with $4 \%$ paraformaldehyde and then incubated with blocking buffer (PBS containing $0.05 \%$ Triton X-100, 0.5\% bovine serum albumin) for $1 \mathrm{hr}$ at room temperature. Following incubation in $2.0 \mathrm{M} \mathrm{HCl}$ for $20 \mathrm{~min}$ at room temperature, cells were washed with $0.1 \mathrm{M}$ sodium borate buffer. Immunostaining was done using primary mouse anti-BrdU antibody (1:100, Roche Applied Science, Indianapolis, IN), and the secondary antibody was Alexa Fluor 594 antimouse antibody (Molecular Probes). The nuclei were counterstained with Hoechst $33342(1 \mu \mathrm{g} / \mathrm{ml})$ for $10 \mathrm{~min}$ at room temperature. The number and the percentage of BrdU-immunopositive cells were calculated in relation to the total number of Hoechst-positive cells (> 1,000 cells).

\section{Staurosporine-induced apoptosis}

FLX $(0.5$ and $1.0 \mu \mathrm{g} / \mathrm{ml})$ was added to NPs for three days, seven days, and two weeks prior to induction of apoptosis by $200 \mathrm{nM} \mathrm{STS.} \mathrm{Twenty} \mathrm{hrs}$ after induction, cells were fixed with $4 \%$ paraformaldehyde and incubated with Hoechst 33342 for $30 \mathrm{~min}$ at room temperature. The number of fragmented nuclei with condensed chromatin, which reliably indicates apoptosis, was determined. The percentage of apoptotic cells was 
calculated in relation to the total number of Hoechst-positive cells ( $>500$ cells).

\section{Real time RT-PCR and quantification of transcripts}

Isolated total RNA from NPs cultured with and without FLX was spiked with recombinant Venus-GFP ( $r$ VenusGFP) RNA ( $300 \mathrm{fg} / \mu \mathrm{g}$ total RNA) as an exogenous control. One microgram of total RNA was reverse transcribed for $60 \mathrm{~min}$ at $42^{\circ} \mathrm{C}$ using SuperScript Reverse Transcriptase (Invitrogen) in a $50 \mu \mathrm{l}$ reaction containing RT buffer (5X) with $500 \mu \mathrm{M}$ random primers, $500 \mu \mathrm{M}$ dNTPs, $10 \mathrm{mM}$ DDT and 40 IU RNaseOUT. After heat inactivation of the reverse transcriptase for $15 \mathrm{~min}$ at $70^{\circ} \mathrm{C}$, samples were diluted to a concentration of $10 \mathrm{ng} / \mu \mathrm{l}$ of input RNA, using nucleasefree water. Quantities of transcripts were detected by real-time RT-PCR, using an $\mathrm{ABI} 7000$ Sequence Detection System and SYBR green chemistry (Applied Biosystems, Foster, CA). The primer pairs were designed using Primer Express Software (Applied Biosystems) and human sequences available on the GenBank database (Suppl. Table 2). After optimizing the reaction conditions for'all primer pairs, $25 \mu \mathrm{l}$ PCR reactions were run in triplicate for each sample. Each reaction mixture consisted of SYBR Green PCR Master Mix (Applied Biosystems), $600 \mathrm{nM}$ of sequence-specific primer pairs, $10 \mathrm{ng}$ of input RNA equivalent template $\mathrm{cDNA}$ and water. For each primer pair, no-RT and no-template samples were run as controls. The thermal cycling profile of the reactions included one cycle at $60^{\circ} \mathrm{C}$ for $2 \mathrm{~min}$, one cycle at $95^{\circ} \mathrm{C}$ for $10 \mathrm{~min}$, and 40 cycles at $95^{\circ} \mathrm{C}$ for $15 \mathrm{sec}$ and at $60^{\circ} \mathrm{C}$ for $1 \mathrm{~min}$. Melting curve analyses were run at the end of each PCR reaction to monitor the PCR product sizes. The relative difference in the initial amount of each cDNA sample was determined by comparing the $\mathrm{C}_{T}$ values. To quantify the mRNA concentrations, standard curves for each gene were generated using five $1 / 10$ serial dilutions from a single stock of human genomic DNA and human reference cDNA mixture (10 pg to 100 $\mathrm{ng}$ ). Before the statistical analyses, the amount of each transcript was normalized to the amount of exogenous control transcript (rVenusGFP) in the same sample.

\section{Western blotting}

NP pellets from cells incubated with and without FLX were collected and kept at $80^{\circ} \mathrm{C}$ until used for western blotting. Briefly, cell lysates were prepared in TNE lysis buffer ( $50 \mathrm{mM}$ Tris, $2 \mathrm{mM}$ EDTA, $5 \mathrm{mM} \mathrm{Na}_{2} \mathrm{P}_{2} \mathrm{O}_{7}, 100$ $\mu \mathrm{M} \mathrm{Na}_{3} \mathrm{VO}_{4}, 5 \mathrm{mM} \mathrm{NaF}, 150 \mathrm{mM} \mathrm{NaCl}, 1 \% \mathrm{NP}-40,1 \mu \mathrm{g} / \mathrm{ml}$ aprotinin, $1 \mu \mathrm{g} /$ $\mathrm{ml}$ leupeptin and $174 \mu \mathrm{g} / \mathrm{ml} \mathrm{PMSF}$ ), incubated on ice for $30 \mathrm{~min}$, and centrifuged at $13,000 \mathrm{rpm}$ for $30 \mathrm{~min}$. Supernatants were evaluated to measure the amount of total protein using the Quick Start Bradford Protein Assay Kit (Bio-Rad, Inc., Hercules, CA). Cell lysates were then treated with SDS sample buffer(Sambrook and Russell, 2001). We loaded approximately $13 \mu \mathrm{g}$ of total protein into each lane of either $10 \%$ or $12 \%$ SDSpolyacrylamide gels. Proteins were separated by electrophoresis at $50 \mathrm{~V}$ for 4 to $6 \mathrm{hrs}$ in a tris-glycine buffer and transferred onto PVDF membrane at $4^{\circ} \mathrm{C}, 100 \mathrm{~mA}$ for $6 \mathrm{hrs}$ in a transfer buffer. Blots were blocked in $5 \% \mathrm{skim}$ milk in tris-buffered saline and $0.1 \%$ Tween 20 (TBST) with agitation for 90 min at room temperature. Primary antibodies were diluted in TBST with $3 \%$ skim milk, using the manufacturer's recommended concentrations: mouse anti-CREB (1:1000, Chemicon), mouse anti-pCREB (Ser133) (1:1000, Cell Signaling Technology, Danvers, MA), mouse anti-5HTT (1:500, Advance Targeting Systems, San Diego, CA), mouse anti-BDNF (1:500; Abcam), and mouse anti- $\beta$ actin (1:1000; Sigma). Blots were incubated overnight at $4^{\circ} \mathrm{C}$ with each primary antibody and subsequently washed with TBST. Alkaline phosphatase-conjugated goat anti-mouse antibody (Bio-Rad) was diluted 1:3000 in TBST with 3\% skim milk. The blots were incubated with the secondary antibody at room temperature for $90 \mathrm{~min}$, and then extensively washed with TBST. Blots were immersed in NBT/BCIP substrate (Roche Applied Science) until the results were visualized. The images were generated by scanning and were analyzed using a densitometer (Bio-Rad).

\section{Statistical analysis}

One-way analysis of variance (ANOVA) and least significant difference
(LSD) procedures were used for the statistical analyses. Quantitative RTPCR results were analyzed using expression values normalized against human GAPDH. The remaining data analysis employed two-tailed Student's $t$ test. Each experiment was conducted at least three times $(n \geq 3)$ and a $p$ value of less than $0.05(p \leq 0.05)$ was considered significantly different.

\section{Acknowledgements}

This project was supported by the Michigan State University Experiment Station, the office of the Vice President for Research and Graduate Studies, the MSU foundation and the Naylor Family foundation.

\section{References}

BARTHOLOMA, P., ERLANDSSON, N., KAUFMANN, K., ROSSLER, O.G. BAUMANN, B., WIRTH, T., GIEHL, K.M. and THIEL, G. (2002). Neuronal cell death induced by antidepressants: lack of correlation with Egr-1, NF-kappa B and extracellular signal-regulated protein kinase activation. Biochem Pharmacol 63: 1507-1516.

BENNINGHOFF, J., SCHMITT, A., MOSSNER, R. and LESCH, K.P. (2002). When cells become depressed: focus on neural stem cells in novel treatment strategies against depression. J Neural Transm 109: 947-962.

BLENDY, J.A. (2006). The role of CREB in depression and antidepressant treatment. Biol Psychiatry 59: 1144-1150.

CASTREN, E. (2005). Is mood chemistry? Nat Rev Neurosci6: 241-246.

CASTREN, E., VOIKAR, V. and RANTAMAKI, T. (2007). Role of neurotrophic factors in depression. Curr Opin Pharmaco/7: 18-21.

CHEN, B., DOWLATSHAHI, D., MACQUEEN, G.M., WANG, J.F. and YOUNG, L.T. (2001). Increased hippocampal BDNF immunoreactivity in subjects treated with antidepressant medication. Biol Psychiatry 50: 260-265.

CHEN, H., PANDEY, G.N. and DWIVEDI, Y. (2006). Hippocampal cell proliferation regulation by repeated stress and antidepressants. Neuroreport 17: 863-867.

CHEN, S.J., KAO, C.L., CHANG, Y.L., YEN, C.J., SHUI, J.W., CHIEN, C.S., CHEN, I.L., TSAI, T.H., KU, H.H. and CHIOU, S.H. (2007). Antidepressant administration modulates neural stem cell survival and serotoninergic differentiation through bcl-2. Curr Neurovasc Res 4: 19-29.

CHIOU, S.H., CHEN, S.J., PENG, C.H., CHANG, Y.L., KU, H.H., HSU, W.M., HO L.L. and LEE, C.H. (2006). Fluoxetine up-regulates expression of cellular FLICE-inhibitory protein and inhibits LPS-induced apoptosis in hippocampusderived neural stem cell. Biochem Biophys Res Commun 343: 391-400.

DE FOUBERT, G., CARNEY, S.L., ROBINSON, C.S., DESTEXHE, E.J., TOMLINSON, R., HICKS, C.A., MURRAY, T.K., GAILLARD, J.P., DEVILLE, C., XHENSEVAL, V. et al. (2004). Fluoxetine-induced change in rat brain expression of brain-derived neurotrophic factor varies depending on length of treatment. Neuroscience 128: 597-604.

DHARA, S.K., HASNEEN, K., MACHACEK, D.W., BOYD, N.L., RAO, R.R. and STICE, S.L. (2008). Human neural progenitor cells derived from embryonic stem cells in feeder-free cultures. Differentiation.

DI LIETO, A., LEO, D., VOLPICELLI, F., DI PORZIO, U. and COLUCCI-D'AMATO, L. (2007). FLUOXETINE modifies the expression of serotonergic markers in a differentiation-dependent fashion in the mesencephalic neural cell line A1 mes c-myc. Brain Res 1143: 1-10.

DIAS, B.G., BANERJEE, S.B., DUMAN, R.S. and VAIDYA, V.A. (2003). Differential regulation of brain derived neurotrophic factor transcripts by antidepressant treatments in the adult rat brain. Neuropharmacology 45: 553-563.

ENCINAS, J.M., VAAHTOKARI, A. and ENIKOLOPOV, G. (2006). Fluoxetine targets early progenitor cells in the adult brain. Proc Nat/ Acad Sci USA 103: 8233-8238.

GENSCHOW, E., SPIELMANN, H., SCHOLZ, G., SEILER, A., BROWN, N., PIERSMA, A., BRADY, M., CLEMANN, N., HUUSKONEN, H., PAILLARD, F. et al. (2002). The ECVAM international validation study on in vitro embryotoxicity tests: results of the definitive phase and evaluation of prediction models. European Centre for the Validation of Alternative Methods. Altern Lab Anim 30 : 151-176.

GOTTLIEB, D.I. (2002). Large-scale sources of neural stem cells. Annu Rev Neurosci25: 381-407. 
GROTE, H.E., BULL, N.D., HOWARD, M.L., VAN DELLEN, A., BLAKEMORE, C., BARTLETT, P.F. and HANNAN, A.J. (2005). Cognitive disorders and neurogenesis deficits in Huntington's disease mice are rescued by fluoxetine. Eur JNeurosci22: 2081-2088.

HISAOKA, K., TAKEBAYASHI, M., NISHIDA, A., TSUCHIOKA, M., YAMAWAKI, S. and NAKATA, Y. (2005). [Mechanisms of antidepressants and serotonin (5HT)-induced glial cell line-derived neurotrophic factor (GDNF) releases in rat C6 gliobrastoma cells]. Nihon Shinkei Seishin Yakurigaku Zasshi25: 25-31.

HISAOKA, K., TAKEBAYASHI, M., TSUCHIOKA, M., MAEDA, N., NAKATA, Y. and YAMAWAKI, S. (2007). Antidepressants Increase Glial Cell Line-Derived Neurotrophic Factor Production through Monoamine-Independent Activation of Protein Tyrosine Kinase and Extracellular Signal-Regulated Kinase in Glial Cells. J Pharmacol Exp Ther321: 148-157.

HUANG, G.J. and HERBERT, J. (2006). Stimulation of neurogenesis in the hippocampus of the adult rat by fluoxetine requires rhythmic change in corticosterone. Biol Psychiatry 59: 619-624.

JOSSELYN, S.A. and NGUYEN, P.V. (2005). CREB, synapses and memory disorders: past progress and future challenges. Curr Drug Targets CNSNeurol Disord 4: 481-497.

KISS, J.Z. and ROUGON, G. (1997). Cell biology of polysialic acid. Curr Opin Neurobio/7: 640-646.

$\mathrm{KOCH}$, J.M., KELL, S. and ALDENHOFF, J.B. (2003). Differential effects of fluoxetine and imipramine on the phosphorylation of the transcription factor CREB and cell-viability. J Psychiatr Res 37: 53-59.

KODAMA, M., FUJIOKA, T. and DUMAN, R.S. (2004). Chronic olanzapine or fluoxetine administration increases cell proliferation in hippocampus and prefrontal cortex of adult rat. Biol Psychiatry 56: 570-580.

LEE, H.J., KIM, J.W., YIM, S.V., KIM, M.J., KIM, S.A., KIM, Y.J., KIM, C.J. and CHUNG, J.H. (2001). Fluoxetine enhances cell proliferation and prevents apoptosis in dentate gyrus of maternally separated rats. Mol Psychiatry6: 610, 725-618.

LEVKOVITZ, Y., GIL-AD, I., ZELDICH, E., DAYAG, M. and WEIZMAN, A. (2005). Differential induction of apoptosis by antidepressants in glioma and neuroblastoma cell lines: evidence for p-c-Jun, cytochrome c, and caspase-3 involvement. J Mol Neurosci27: 29-42.

LIN, T.M., TSAI, J.L., LIN, S.D., LAI, C.S. and CHANG, C.C. (2005). Accelerated growth and prolonged lifespan of adipose tissue-derived human mesenchymal stem cells in a medium using reduced calcium and antioxidants. Stem Cells Dev 14: 92-102.

MALBERG, J.E. (2004). Implications of adult hippocampal neurogenesis in antidepressant action. J Psychiatry Neurosci29: 196-205.

MALBERG, J.E. and BLENDY, J.A. (2005). Antidepressant action: to the nucleus and beyond. In Trends Pharmaco/ Sci, vol. 26 (ed., pp. 631-638.

MALBERG, J.E. and DUMAN, R.S. (2003). Cell proliferation in adult hippocampus is decreased by inescapable stress: reversal by fluoxetine treatment. Neuropsychopharmacology 28: 1562-1571.

MALBERG, J.E., EISCH, A.J., NESTLER, E.J. and DUMAN, R.S. (2000). Chronic antidepressant treatment increases neurogenesis in adult rat hippocampus. $J$ Neurosci20: 9104-9110.

MANEV, H., UZ, T., SMALHEISER, N.R. and MANEV, R. (2001). Antidepressants alter cell proliferation in the adult brain in vivo and in neural cultures in vitro. Eur J Pharmacol411: 67-70.

MORRISON, J.L., RIGGS, K.W. and RURAK, D.W. (2005). Fluoxetine during pregnancy: impact on fetal development. Reprod Fertil Dev 17: 641-650.

NAHON, E., ISRAELSON, A., ABU-HAMAD, S. and VARDA, S.B. (2005). Fluoxetine (Prozac) interaction with the mitochondrial voltage-dependent anion channel and protection against apoptotic cell death. FEBS Lett579: 5105-5110.

NAKAGAWA, S., KIM, J.E., LEE, R., CHEN, J., FUJIOKA, T., MALBERG, J., TSUJI, S. and DUMAN, R.S. (2002). Localization of phosphorylated cAMP response element-binding protein in immature neurons of adult hippocampus. JNeurosCi 22: $9868-9876$
NESTLER, E.J., BARROT, M., DILEONE, R.J., EISCH, A.J., GOLD, S.J. and MONTEGGIA, L.M. (2002). Neurobiology of depression. Neuron 34: 13-25.

NIBUYA, M., MORINOBU, S. and DUMAN, R.S. (1995). Regulation of BDNF and trkB mRNA in rat brain by chronic electroconvulsive seizure and antidepressant drug treatments. JNeurosci 15: 7539-7547.

NIBUYA, M., NESTLER, E.J. and DUMAN, R.S. (1996). Chronic antidepressant administration increases the expression of cAMP response element binding protein (CREB) in rat hippocampus. J Neurosci 16: 2365-2372.

ONGUR, D., DREVETS, W.C. and PRICE, J.L. (1998). Glial reduction in the subgenual prefrontal cortex in mood disorders. Proc Natl Acad Sci U S A 95: 13290-13295.

POUTON, C.W. and HAYNES, J.M. (2007). Embryonic stem cells as a source of models for drug discovery. Nat Rev Drug Discov6: 605-616.

RAJKOWSKA, G., MIGUEL-HIDALGO, J.J., WEI, J., DILLEY, G., PITTMAN, S.D. MELTZER, H.Y., OVERHOLSER, J.C., ROTH, B.L. and STOCKMEIER, C.A. (1999). Morphometric evidence for neuronal and glial prefrontal cell pathology in major depression. Biol Psychiatry 45: 1085-1098.

SAIRANEN, M., LUCAS, G., ERNFORS, P., CASTREN, M. and CASTREN, E. (2005). Brain-derived neurotrophic factor and antidepressant drugs have differ ent but coordinated effects on neuronal turnover, proliferation, and survival in the adult dentate gyrus. J Neurosci25: 1089-1094.

SAMBROOK, J. and RUSSELL, D.W. (2001). Molecular cloning: a laboratory manual. Cold Spring Harbor Laboratory Press, Cold Spring Harbor, N.Y.

SANTARELLI, L., SAXE, M., GROSS, C., SURGET, A., BATTAGLIA, F., DULAWA S., WEISSTAUB, N., LEE, J., DUMAN, R., ARANCIO, O. et al. (2003). Requirement of hippocampal neurogenesis for the behavioral effects of antidepressants. Science 301: 805-809.

SCHECHTER, L.E., RING, R.H., BEYER, C.E., HUGHES, Z.A., KHAWAJA, X. MALBERG, J.E. and ROSENZWEIG-LIPSON, S. (2005). Innovative approaches for the development of antidepressant drugs: current and future strategies. NeuroRx 2: 590-611.

SCHOLZ, G., POHL, I., GENSCHOW, E., KLEMM, M. and SPIELMANN, H. (1999). Embryotoxicity screening using embryonic stem cells in vitro: correlation to in vivo teratogenicity. Cells Tissues Organs 165: 203-211.

SERAFEIM, A., HOLDER, M.J., GRAFTON, G., CHAMBA, A., DRAYSON, M.T., LUONG, Q.T., BUNCE, C.M., GREGORY, C.D., BARNES, N.M. and GORDON J. (2003). Selective serotonin reuptake inhibitors directly signal for apoptosis in biopsy-like Burkitt lymphoma cells. Blood 101: 3212-3219.

THOMSON, J.A., ITSKOVITZ-ELDOR, J., SHAPIRO, S.S., WAKNITZ, M.A. SWIERGIEL, J.J., MARSHALL, V.S. and JONES, J.M. (1998). Embryonic stem cell lines derived from human blastocysts. Science 282: 1145-1147.

VAREA, E., BLASCO-IBANEZ, J.M., GOMEZ-CLIMENT, M.A., CASTILLO-GOMEZ, E., CRESPO, C., MARTINEZ-GUIJARRO, F.J. and NACHER, J. (2006). Chronic Fluoxetine Treatment Increases the Expression of PSA-NCAM in the Medial Prefrontal Cortex. Neuropsychopharmacology.

WOBUS, A.M. and BOHELER, K.R. (2005). Embryonic stem cells: prospects for developmental biology and cell therapy. Physiol Rev 85: 635-678.

WOBUS, A.M., KLEPPISCH, T., MALTSEV, V. and HESCHELER, J. (1994). Cardiomyocyte-like cells differentiated in vitro from embryonic carcinoma cells P19 are characterized by functional expression of adrenoceptors and $\mathrm{Ca} 2+$ channels. In vitro Cell Dev Biol Anim 30A: 425-434.

WOBUS, A.M., WALLUKAT, G. and HESCHELER, J. (1991). Pluripotent mouse embryonic stem cells are able to differentiate into cardiomyocytes expressing chronotropic responses to adrenergic and cholinergic agents and $\mathrm{Ca} 2+$ channe blockers. Differentiation 48: 173-182

WONG, D.T., PERRY, K.W. and BYMASTER, F.P. (2005). Case history: the discovery of fluoxetine hydrochloride (Prozac). Nat Rev Drug Discov 4: 764774.

ZHANG, S.C., WERNIG, M., DUNCAN, I.D., BRUSTLE, O. and THOMSON, J.A. (2001). In vitro differentiation of transplantable neural precursors from human embryonic stem cells. Nat Biotechno/19: 1129-1133. 


\section{Further Related Reading, published previously in the Int. J. Dev. Biol.}

See Special Issue Pattern Formation edited by Michael K. Richardson and Cheng-Ming Chuong at:

http://www.ijdb.ehu.es/web/contents.php?vol=53\&issue=5-6

Mouse ES cells over-expressing the transcription factor NeuroD1 show increased differentiation towards endocrine lineages and insulin-expressing cells

Mlanie Marchand, Insa S. Schroeder, Suzy Markossian, Anouchka Skoudy, Didier Nègre, François-Loïc Cosset, Paco Real, Christian Kaiser, Anna M. Wobus and Pierre Savatier

Int. J. Dev. Biol. (2009) 53: 569-578

Mechanical control of tissue morphogenesis during embryological development Donald E. Ingber

Int. J. Dev. Biol. (2006) 50: 255-266

Mouse induced pluripotent stem cells

Eamon Geoghegan and Lucy Byrnes

Int. J. Dev. Biol. (2008) 52: 1015-1022

Neural differentiation from human embryonic stem cells in a defined adherent culture condition

Hossein Baharvand, Narges-Zare Mehrjardi, Maryam Hatami, Sahar Kiani, Mahendra

Rao and Mahdi-Montazer Haghighi

Int. J. Dev. Biol. (2007) 51: 371-378

Transforming growth factor beta2 promotes the formation of the mouse cochleovestibular ganglion in organ culture

Junko Okano, Toshiya Takigawa, Kenji Seki, Shigehiko Suzuki, Kohei Shiota and Makoto Ishibashi

Int. J. Dev. Biol. (2005) 49: 23-31

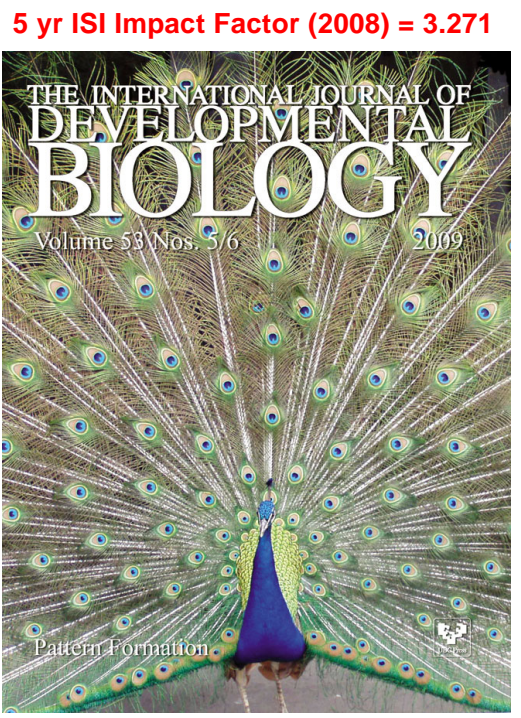

